\title{
Soyabean (Glycine max) Response to Applied Fertilizers through INM on Deep Black Soil of Marathwada Region in Relation to Available Nitrogen, Phosphorus, Potassium and Suphur
}

\author{
Ghodke Pallavi Dipak $^{1^{*}}$ and Takankhar Vilas Govindrao ${ }^{2}$
}

${ }^{1}$ Department of Soil science and Agriculture, Chemistry, Jaywantrao Bhosale Krishna College of Agriculture, Rethare Bk, (Affiliated to Mahatma Phule Krishi Vidyapeeth, Rahuri) Tal, Karad Dist.- Satara 415108 Maharashtra, India

${ }^{2}$ Department of Soil Science and Agriculture Chemistry College of Agriculture, Latur, Dist. Latur Vasantrao Naik Marathwada Agricultural University, Parbhani Maharashtra, India

\author{
*Corresponding author
}

\section{A B S T R A C T}

\section{Keywords}

Nitrogen,

Phosphorus,

Potassium and

Sulphur

\section{Article Info}

Accepted:

12 October 2020

Available Online:

10 November 2020

\begin{abstract}
A field experiment was conducted on deep black soil with calcareous in nature and slightly alkaline in reaction at departmental research farm, College of Agriculture Latur during Kharif season of 2008-2009 on Soybean crop variety MAUS-71 (Sammrudhi). The experiment was conducted in $\mathrm{RBD}$ comprising three replications and nine treatments .Available nutrients viz. $\mathrm{N}, \mathrm{P}, \mathrm{K}$ and $\mathrm{S}$ content in soil was higher at $\mathrm{T}_{9}(100 \% \mathrm{RDF}+10 \mathrm{t}$ FYM ha $^{-1}+45 \mathrm{~kg} \mathrm{~S}^{-1}+$ Biofertilizer $)$ and $\mathrm{T}_{8}\left(50 \% \mathrm{RDF}+10 \mathrm{t} \mathrm{FYM} \mathrm{ha}^{-1}+45 \mathrm{~kg} \mathrm{~S} \mathrm{ha}^{-1}+\right.$ Biofertilizer) than the rest of the treatments. It was also observed that the available nutrients in post harvest soil samples were higher as compared to the initial soil samples. There was a significant increase available N, P, K and S over initial soil samples with treatments having combined application of chemical fertilizers along with enough bulk of farm yard manure. Available nitrogen (197.5 $\mathrm{kg} \mathrm{ha}^{-1}$ ), phosphorus( $26.88 \mathrm{~kg} \mathrm{ha}{ }^{-1}$ ), potassium $\left(311.0 \mathrm{~kg} \mathrm{ha}^{-1}\right)$, and sulphur (17.95 $\left.\mathrm{kg} \mathrm{ha}^{-1}\right)$ was significantly higher with treatment $\left(\mathrm{T}_{9}\right) 100 \% \mathrm{RDF}+10 \mathrm{t} \mathrm{FYM} \mathrm{ha}^{-1}+45 \mathrm{~kg} \mathrm{~S}^{-1}+$ Biofertilizer in soil over rest of the treatments however significantly lower available nitrogen (171.43 $\left.\mathrm{kg} \mathrm{ha}^{-1}\right)$, phosphorus $\left(21.18 \mathrm{~kg} \mathrm{ha}^{-1}\right)$, potassium $\left(250.0 \mathrm{~kg} \mathrm{ha}^{-1}\right)$, sulphur $\left(15.59 \mathrm{~kg} \mathrm{ha}^{-1}\right)$ in soil was recorded due to treatment T1 (control).
\end{abstract}

\section{Introduction}

Soybean thrives best on a wide range of $\mathrm{pH}$ and soil types and there must be good rooting conditions along with balanced nutrition for obtaining higher yield. Being a legume plant, soybean has ability to fix atmospheric nitrogen with the help of bacteria and to add organic matter in the soil, thereby increasing the productivity of soil.

In last 2-3 decades there is substantial increase in command area and there by intensive cropping. It has resulted in increase 
in cost of fertilizer and low purchasing power of farmer has restricted the use of chemical fertilizers for increasing crop production. Under such condition it has become imperative to use all the available resources of plant nutrients in a judicious way to minimize, fertilizers use and at the same on a long term basis. The base for crop production and improvement of soil fertility is mineral nutrition. Therefore efficient management of organic and inorganic sources is a prerequisite for achieving continuous productivity of cops in an economically and ecologically sustainable manner.

Thus for maintenance of the soil fertility, productivity and soil health with the FYM, compost and other organic sources are gaining importance. Biofertilizers cannot replace chemical fertilizers, but certainly are capable of reducing their input. Seed inoculation with effective Rhizobium inoculants is recommended to ensure adequate nodulation and $\mathrm{N}_{2}$ fixation for maximum growth and yield of pulse crop. Intensive cropping coupled with increased use of $\mathrm{N}$ and $\mathrm{P}$ fertilizer, lower use of organic manures and very low rates of application of $\mathrm{K}$ and $\mathrm{S}$ in most of soils of this region have started depleting and are limiting soil productivity. Keeping these in view the present investigation was undertaken for assessing the residual effect of INM on available nutrients in soil.

\section{Materials and Methods}

The field experiment was conducted at Research farm, Department of soil science and Agril. Chemistry, College of Agriculture, Latur during Kharif season of 2008-2009. using soybean (MAUS-71) as a test crop. Available nitrogen was determined by Alkaline Potassium permanganate method as suggested by Subbiah and Asija, (1956). Available phosphorus was extracted from the soil with $0.5 \mathrm{M}$ sodium bicarbonate at nearly constant $\mathrm{pH} 8.5$ by Olsen's method. Available potassium was determined with neutral normal NH4OAC by flame photometer (Piper, 1966) and available sulphur was determined by terbidimetric method as given by Williams and Steinbergs, (1959) respectively. The experiment was conducted in RBD comprising three replications and nine treatments viz. $\mathrm{T}_{1}(100 \% \mathrm{RDF}), \mathrm{T}_{2}(100 \%$ $\left.\mathrm{RDF}+10 \mathrm{t} \mathrm{FYM} \mathrm{ha}^{-1}\right) \mathrm{T}_{3}(50 \% \mathrm{RDF}+10 \mathrm{t}$ FYM ha ${ }^{-1}+$ Biofertilizer $) . \mathrm{T}_{4}(100 \% \mathrm{RDF}+10$ t FYM ha ${ }^{-1}+$ Biofertilizer). $\mathrm{T}_{5}(100 \% \mathrm{RDF}+$ $\left.45 \mathrm{Kg} \mathrm{S} \mathrm{ha}^{-1}\right) \cdot \mathrm{T}_{6}\left(50 \% \mathrm{RDF}+10 \mathrm{t} \mathrm{FYM} \mathrm{ha}{ }^{-1}+\right.$ $\left.45 \mathrm{~kg} \mathrm{~S} \mathrm{ha}^{-1}\right) \cdot \mathrm{T}_{7}\left(100 \% \mathrm{RDF}+45 \mathrm{~kg} \mathrm{~s} \mathrm{ha}^{-1}+\right.$ Biofertilizer). $\mathrm{T}_{8}\left(50 \% \mathrm{RDF}+10 \mathrm{t} \mathrm{FYM} \mathrm{ha}^{-1}\right.$ $+45 \mathrm{~kg} \mathrm{~S} \mathrm{ha}^{-1}+$ Biofertilizer). $\mathrm{T}_{9}(100 \% \mathrm{RDF}$ +10 t FYM ha ${ }^{-1}+45 \mathrm{~kg} \mathrm{~S}^{-1}+$ Biofertilizer). The experimental soil was deep black with clay in texture, calcareous in nature and slightly alkaline in reaction. Before sowing initial soil sample was collected from $0-15 \mathrm{~cm}$ depth covering experimental area which was analysed for various physico-chemical properties presented in table 1 .

\section{Results and Discussion}

Available nutrients viz., N,P,K and $\mathrm{S}$ were analyzed from representative soil samples collected from different plots after harvest of soybean crop are presented in table 2 .

\section{Available nitrogen}

The results regarding residual effect of INM on available nitrogen in soil after harvest of soybean crop is presented in table 2 . Available nitrogen in soil was affected significantly due to different treatments. It is evident from the results that the treatment $\mathrm{T} 9$ (100 RDF \%+ 10 t FYM ha ${ }^{-1}+45 \mathrm{~kg} \mathrm{~s} \mathrm{ha}^{-1}+$ Biofertilizer) was recorded significantly higher available nitrogen $\left(197.5 \mathrm{~kg} \mathrm{ha}^{-1}\right)$ was in soil over rest of the treatments, however it was at par with treatment T8 $(50 \% \mathrm{RDF}+10$ 
t FYM ha ${ }^{-1}+45 \mathrm{~kg} \mathrm{~s} \mathrm{ha}^{-1}+$ Biofertilizer), T4 $\left(100 \mathrm{RDF}+10 \mathrm{t} \mathrm{FYM} \mathrm{ha}^{-1}+\right.$ Biofertilizer $)$ and T2 (100 RDF + 10 t FYM ha $\left.{ }^{-1}\right)$. Significantly lower available nitrogen content $\left(171.43 \mathrm{~kg} \mathrm{ha}^{-1}\right)$ was noted due to treatment T1 (control).

Further data revealed that the nitrogen content in soil after harvest of soybean crop was increased up to $22 \mathrm{~kg}$ ha- 1 treatment $\mathrm{T} 9$ than the initial nitrogen content. In other treatments it was increased by 10 to $20 \mathrm{~kg} \mathrm{ha}^{-1}$ except treatment T1. Similar results were also recorded by Laxminarayana and Patiram (2005).

Tiwari et al., (2002) stated that the inclusion of FYM in the fertilizer treatments schedule improved the organic carbon status and available $\mathrm{N}, \mathrm{P}, \mathrm{K}$ and $\mathrm{S}$ in soil thereby sustain the soil health.

Available nitrogen positively increased with the application of different organic manures. The organic manures directly adds organic matter in to the soil, that resulted in buildup of high organic matter as well as available $\mathrm{N}$ status of the soil.

The available $\mathrm{N}$ content in soil increased with application of 10\% RDF along with FYM due to higher organic carbon content of the soil (Murrugappan et al., 1998).

Farmyard manure also improves the physical properties of the soil thus creating favourable conditions for microbial activity that results in nutrient availability (Sharma et al., 2002).

Table.1 Physico-Chemical properties of soil as influenced by INM

\begin{tabular}{|c|l|c|c|}
\hline Sr. No. & Soil parameters & \multicolumn{2}{|c|}{ Estimate and units } \\
\hline $\mathbf{A})$ & Physical parameters & & \\
\hline $\mathbf{1}$ & Coarse sand & 15.10 & Per cent \\
\hline $\mathbf{2}$ & Fine sand & 17.90 & Per cent \\
\hline $\mathbf{3}$ & Silt & 23.55 & Per cent \\
\hline $\mathbf{4}$ & Clay & 43.45 & Per cent \\
\hline $\mathbf{5}$ & Textural class & Clayey & \\
\hline $\mathbf{6}$ & Bulk density & 1.29 & $\mathrm{Mg} \mathrm{m}^{-3}$ \\
\hline $\mathbf{7}$ & Particle density & 2.44 & $\mathrm{Mg} \mathrm{m}^{-3}$ \\
\hline $\mathbf{8}$ & Porosity & 48.50 & Per cent \\
\hline $\mathbf{B})$ & Fertility parameters & & \\
\hline $\mathbf{1}$ & pH & 8.40 & \\
\hline $\mathbf{2}$ & EC & 0.16 & $\mathrm{dsm}^{-1}$ \\
\hline $\mathbf{3}$ & Organic carbon & 0.31 & $\mathrm{Per} \mathrm{cent}^{\mathrm{n}}$ \\
\hline $\mathbf{4}$ & CaCo & 5.00 & $\mathrm{Per} \mathrm{cent}_{3}$ \\
\hline $\mathbf{5}$ & Available nitrogen & 175.61 & $\mathrm{Kg} \mathrm{ha}^{-1}$ \\
\hline $\mathbf{6}$ & Available phosphorus & 22.44 & $\mathrm{Kg} \mathrm{ha}^{-1}$ \\
\hline $\mathbf{7}$ & Available potassium & 243.15 & $\mathrm{Kg} \mathrm{ha}^{-1}$ \\
\hline $\mathbf{8}$ & Available sulphur & 16.25 & $\mathrm{Kg} \mathrm{ha}^{-1}$ \\
\hline
\end{tabular}


Table.2 Effect of INM on available nutrients in soil

\begin{tabular}{|c|c|c|c|c|}
\hline Treatment details & $\begin{array}{c}\text { Available } \\
\text { phosphorus } \\
\left(\mathrm{kg} \mathrm{ha}^{-1}\right)\end{array}$ & $\begin{array}{c}\text { Available } \\
\text { phosphorus } \\
\left(\mathrm{kg} \mathrm{ha}^{-1}\right)\end{array}$ & $\begin{array}{c}\text { Available } \\
\text { phosphorus } \\
\left(\mathrm{kg} \mathrm{ha}^{-1}\right)\end{array}$ & $\begin{array}{c}\text { Available } \\
\text { potassium }\left(\mathrm{kg}^{-1}\right) \\
\left.\text { ha }^{-1}\right)\end{array}$ \\
\hline $\mathrm{T}_{1}(\mathbf{1 0 0 \%} \mathrm{RDF})$ & 171.43 & 21.18 & 250 & 15.59 \\
\hline $\mathrm{T}_{2}\left(100 \% \mathrm{RDF}+10+\mathrm{FYM} \mathrm{ha}^{-1}\right)$ & 190.60 & 24.40 & 286 & 17.08 \\
\hline $\begin{array}{l}\mathrm{T}_{3}\left(50 \% \text { RDF }+10+\text { FYM ha }^{-1}+\right. \\
\text { Biofertilizer })\end{array}$ & 185.60 & 23.31 & 272 & 16.16 \\
\hline $\begin{array}{l}\mathrm{T}_{4}\left(100 \% \text { RDF }+10+\mathrm{FYM} \mathrm{ha}^{-1}+\right. \\
\text { Biofertilizer })\end{array}$ & 192.40 & 24.82 & 294 & 10.25 \\
\hline $\mathrm{T}_{5}\left(100 \% \mathrm{RDF}+45 \mathrm{Kg} \mathrm{S} \mathrm{ha}^{-1}\right)$ & 176.65 & 22.26 & 258 & 15.35 \\
\hline $\begin{array}{l}\mathrm{T}_{6}\left(50 \% \mathrm{RDF}+10 \mathrm{t} \mathrm{FYM} \mathrm{ha}^{-1}+45 \mathrm{~kg}\right. \\
\left.\mathrm{S} \mathrm{ha}^{-1}\right)\end{array}$ & 187.30 & 23.92 & 279 & 16.46 \\
\hline $\begin{array}{l}\mathrm{T}_{7}\left(100 \% \mathrm{RDF}+45 \mathrm{~kg} \mathrm{~S} \mathrm{ha}^{-1}+\right. \\
\text { Biofertilizer })\end{array}$ & 185.00 & 22.68 & 265 & 15.58 \\
\hline $\begin{array}{l}\text { T }_{8}(50 \% \text { RDF+10 t FYM ha } \\
\text { kg S ha }^{-1}+45 \\
\text { Biofertilizer })\end{array}$ & 195.20 & 25.41 & 302 & 17.56 \\
\hline $\begin{array}{l}\text { T, }_{9}(100 \% \text { RDF }+10 \text { t FYM ha } \\
\operatorname{kg~S~ha~}^{-1}+45 \\
\text { Biofertilizer })\end{array}$ & 197.50 & 26.88 & 311 & 17.95 \\
\hline Initial & 175.61 & 22.44 & 243.15 & 16.25 \\
\hline S.E. \pm & 2.44 & 0.51 & 14.03 & 0.76 \\
\hline CD at $5 \%$ & 7.34 & 1.54 & 42.09 & 2.28 \\
\hline
\end{tabular}

Available phosphorus

The data on residual effect of integrated nutrient management on available phosphorus in soil at harvest of soybean crop presented in table 2. The data indicated that treatment $\mathrm{T} 9$ $\left(100\right.$ RDF \%+ 10 t FYM ha ${ }^{-1}+45 \mathrm{~kg} \mathrm{~s} \mathrm{ha}^{-1}+$ Biofertilizer) showed significantly highest available phosphorus in soil after harvest of soybean crop than the rest of the treatments. However, it was at par with the treatment T8 (50 RDF \% + 10 t FYM ha ${ }^{-1}+45 \mathrm{~kg} \mathrm{~s} \mathrm{ha}^{-1}+$ Biofertilizer). Lower available $\mathrm{P}$ content was recorded due to treatment $\mathrm{T} 1$ (control). It was also observed from the results that the available phosphorus in soil (post harvest soil samples) was increased by $4,5,3$ and 2.4 over initial soil $\mathrm{P}$ (22.44 $\left.\mathrm{kgha}^{-1}\right)$ due to treatment $\mathrm{T} 9, \mathrm{~T} 8$ and $\mathrm{T} 4$ respectively. These results are in accordance with the results of Mann et al., (2006). They reported that application of NPK with 10 tonnes farmyard manure $\mathrm{ha}^{-1}$ gave higher $\mathrm{p}$ contents than that with addition of NPK without farmyard manure.

Solanki et al., (2006) showed that application of FYM @ $10 \mathrm{t} \mathrm{ha}^{-1}$ significantly increased the available nitrogen by 31.4 , phosphorus by 27.3 and potassium by 62.8 percent as compared to only application of $100 \%$ RDF. The increase in soil nutrients after harvest of crop was due to addition of these nutrients through the application of FYM, farm waste and animal litter. Addition to these nutrients through the application of FYM, farm waste and animal litter. Addition to these carbon dioxide and organic acid released during the process of decomposition cause to increase the availability of nutrients from native as well as applied organic fertilizers. These might have contributed towards increased available nutrient status of soil with respect to these nutrients. 


\section{Available potassium}

The data on residual effect of integrated nutrient management on available potassium in soil after harvest of soybean crop is presented in table 2 . The data indicated that treatment T9 (100 RDF \%+ $10 \mathrm{t} \mathrm{FYM} \mathrm{ha}^{-1}$ $+45 \mathrm{~kg} \mathrm{~S} \mathrm{ha}{ }^{-1}+$ Biofertilizer) significantly increased available potassium $\mathrm{K}\left(311 \mathrm{kgha}^{-1}\right)$ in soil after harvest of soybean while it ws at par with treatment T8 (50 RDF \% + 10 t FYM $\mathrm{ha}^{-1}+45 \mathrm{~kg} \mathrm{~S} h a^{-1}+$ Biofertilizer). T4 (100 $\% \mathrm{RDF}+10 \mathrm{t} \mathrm{FYM} \mathrm{ha}^{-1}+$ Biofertilizer) and T2 (100\%RDF + 10 t FYM ha $\left.{ }^{-1}\right)$, T6 (50 $\left.\% \mathrm{RDF}+10 \mathrm{t} \mathrm{FYM} \mathrm{ha}^{-1}+45 \mathrm{~kg} \mathrm{~S} \mathrm{ha}^{-1}\right)$ and T3 (50\%RDF + 10 t FYM ha ${ }^{-1}+$ Biofertilizer). Significantly lower available $\mathrm{k}$ content in soil $\left(250 \mathrm{~kg} \mathrm{ha}^{-1}\right)$ was recoded with the treatment $\mathrm{T} 1$ (control).

Data in table further revealed that the available potassium in soil (after harvest of soybean crop) was increased from 7 to $43 \mathrm{~kg}$ $\mathrm{ha}^{-1}$ than the initial soil. This increase was higher due to treatment $\mathrm{T} 9$ lower due to treatment T1 (control).

Bharadwaj et al., (1994) observed that fym treated plots show a further increase in the available $\mathrm{N}, \mathrm{P}$ and $\mathrm{K}$ of the soils. The increase in available $\mathrm{N}, \mathrm{P}$ and $\mathrm{K}$ due to FYM application may be because of the direct addition of NPK through FYM to the available pool of the soil. The decomposition of organic matter is accompanied by the release of appreciable quantities of carbon dioxide which when dissolved in water, forms carbonic acid, which is capable of decomposing certain primary minerals.

The beneficial effect of FYM on the available $\mathrm{K}$ is also due to the reduction of potassium fixation and release of $K$ due to the interaction of organic matter with clay besides the direct potassium addition in the available $\mathrm{K}$ pool of the soil. These results are in conformity with the results of Tondon (1988).

\section{Available sulphur}

The results regarding residual effect of integrated nutrient management on available sulphur in soil after harvest of soybean crop are presented in table. The results showed that treatment T9 (100 RDF \% + 10 t FYM ha ${ }^{-1}$ $+45 \mathrm{~kg} \mathrm{~S} \mathrm{ha}{ }^{-1}+$ Biofertilizer) recorded significantly highest available sulphur in soil collected after harvest of soybean that the rest of treatments, however it was at par with treatment T8 (50 RDF \% + 10 t FYM ha $^{-1}+$ $45 \mathrm{~kg} \mathrm{~s} \mathrm{ha}^{-1}+$ Biofertilizer . T4 (100\%RDF + 10 t FYM ha ${ }^{-1}+$ Biofertilizer), T2 (100 $\left.\% \mathrm{RDF}+10 \mathrm{t} \mathrm{FYM} \mathrm{ha}^{-1}\right)$ and T6 (50\%RDF + $10 \mathrm{t} \mathrm{FYM} \mathrm{ha}^{-1}+45 \mathrm{~kg} \mathrm{Sha}^{-1}$ ).

Higher (17.95 $\left.\mathrm{kgha}^{-1}\right)$ and lower (15.59 $\left.\mathrm{kgha}^{-1}\right)$ available sulphur content in soil was observed due to treatment T9 and T1(control) respectively.

Further data revealed that the available $\mathrm{S}$ content in soil was improved in post harvest soil than the initial soil. It was increased by 3.0, 1.7 and $1.3 \mathrm{kgha}^{-1}$ over initial content due to T4, T9 and T8. This might be due to combined application of recommended dose of fertilizer and organics improved the availability of sulphur in soil.

Tiwari et al., (2002) reported favourable effect of FYM along with recommended dose of fertilizer in improving the availability of sulphur in soil. Similarly, Kademani et al., (2003) also reported the advantage of the combined use of organic and inorganic sources on the availability of sulphur in soil.

\section{References}

Anonymous (2008). Stage wise area and production of oilseeds in India. www. India Agronet.com. 
Bharadwaj, V. and Omanwar, P.K. (1994). Long term effects of continuous rotational cropping and fertilization on crop yields and soil properties, $\mathrm{EC}, \mathrm{pH}$, $\mathrm{OM}$ and available nutrients on soil. Indian Soc. Soil Sci. 42(3): 387-392.

Laxminarayana, K. and Patiram,(2005). Influence of inorganic, biological and organic manures on yield and nutrient uptake of groundnut (Arachis hypogaea) and soil properties. Indian j. Agric. Sci. 75(4):218-221.

Mann, K.K., Brar, B.S. and Dhillon, N.S.(2006). Influence of long term use of farmyard manure and inorganic fertilizers on nutrient availability in a Typic Ustrochrept Indian J.Agric.Sci., 45(2):288-292.

Murugappan, V., Santhy, P., Selvi, D. and Perumal Rani, (1998). Long term fertilizer experiment with intensive cropping on Inceptisol. Proceedings of National workshop on soil fertility management through integrated plant nutrient supply. Indian Institute Soil Sci., Bhopal, India, PP 194-205.

Olsen, S.R., Cole, C.V., Watanabe, F.S. and Dean, L.A. (1954). Estimation of available phosphorus in soil by extraction with $\mathrm{NaHCO}$. USDA cir 939 (quoted from Methods of Soil Analysis C.A. Black (ed) (1965) Am. Soc. Agron. Inc. Madison Wisconsin USA. pp 1035.

Piper, C.S. 1966. Soil and plant analysis. Hans Publications Bombay. pp. 368.
Sharma, S.C., Vyas, A.K. and Shaktawat, M.S., (2002). Effect of leaves and sources of phosphorus under the influence of farm yard manure on growth determinants and productivity of soybean. Indian J.Agric.Res.,36(2):123127.

Solanki, R.M., Bhalu, V.B. and Jadhav, K.V. (2006). Organic farming approach for sustaining productivity of rainfed groundnut. Ann.Agric.Res.27(3):236239.

Subbaih, B.V. and Asija, G.L. 1956. A rapid procedure for the estimation of available nitrogen in soils. Curr. Sci. 25: 259-260.

Tiwari, A., Dwivedi, A. K. and Dikshit, P.R. (2002). Long term influence of organic and inorganic fertilization on soil fertility and productivity Of soybean wheat system in a Vertisol. J. Indian Soc. Soil Sci. 50(4):472-475.

Tandon, H.L.S. 19. Potassium research and agricultural production in India. FDCO, New Delhi.

William, C.M. and Steinbergs, A. 1956. Soil sulphur fractions as chemical indices of available sulphur in some Australian Soils. Aust. J. Agric.Res.10: 340-352.

Jenkinson, D.S. and Johnson, A. E.(1977). Soil organic matter in the Hoosefield continuous barley experiment. Rothamsted Experiment Station, Annual Report 1976, Part II, PP 87-101.

\section{How to cite this article:}

Ghodke Pallavi Dipak and Takankhar Vilas Govindrao. 2020. Soyabean (Glycine max) Response to Applied Fertilizers through INM on Deep Black Soil of Marathwada Region in Relation to Available Nitrogen, Phosphorus, Potassium and Suphur. Int.J.Curr.Microbiol.App.Sci. 9(11): 1609-1614. doi: https://doi.org/10.20546/ijcmas.2020.911.191 